\title{
Patterns of Sudanophilic Lesions at Ostia of Descending Thoracic and Abdominal Aorta in Cholesterol-Fed Adult Rabbits
}

\author{
Patrones de Lesiones Sudanofílicas en el Ostio de las Partes Torácica \\ y Abdominal de la Aorta en Conejos Adultos Alimentados con Colesterol
}

"Uzma Shahid; **Shadab Ahmed Butt \& ****Nusrat Zareen

SHAHID, U.; BUTT, S. A. \& ZAREEN, N. Patterns of sudanophilic lesions at ostia of descending thoracic and abdominal aorta in cholesterol-fed adult rabbits. Int. J. Morphol., 29(3):742-746, 2011.

SUMMARY: Sudan-positive atherosclerotic lesions preferentially occur at downstream and lateral margins of arterial branch ostia in human neonates and weanling rabbits but tend to develop at lateral and upstream margins in old subjects. We investigated (i) the pattern of sudanophilic lesions at aortic ostia of cholesterol-fed adult rabbits and (ii) determined any differences in lesion distribution between descending thoracic and abdominal aorta. Ten adult males, New Zealand white rabbits were fed $2 \%$ high cholesterol diet. After six weeks, aortas were excised, opened longitudinally and stained with Sudan-IV for gross examination of atherosclerotic lesions. A total of 156 descending thoracic and 90 abdominal ostia were examined. Mean lesion frequencies upstream, downstream and at lateral margins of the affected ostia were calculated and compared. Sudanophilic lesions were detected around 32\% ostia of descending thoracic aorta and $25 \%$ those of abdominal aorta. At ostia of descending thoracic aorta, lesion frequencies were significantly higher $(\mathrm{P}<0.001)$ downstream $(95 \%)$ and at lateral margins (92\%) than upstream (2\%). In abdominal aorta, lateral (100\%) and upstream (43\%) margins were significantly $(\mathrm{P}<0.05)$ more affected while minimal lesion frequencies were seen at downstream branch points $(9 \%)$. Comparison between descending thoracic and abdominal aorta showed an insignificant difference of lesion frequencies at lateral margins $(\mathrm{P}>0.05)$ but a highly significant difference at upstream versus downstream of ostia $(\mathrm{P}<0.001)$. We concluded that in cholesterol-fed adult rabbits, juvenile pattern of downstream lipid deposition persists at ostia of descending thoracic aorta while a switch towards the upstream pattern of old subjects occurs at ostia of abdominal aorta.

KEY WORDS: Sudanophilic lesions; Aorta; Ostia; Rabbits.

\section{INTRODUCTION}

Atherosclerosis is characterized by patchy accumulation of lipids, predominantly at the ostia compared to the non-branched segments of arterial wall. Rate-limiting steps involved in the development of this global health problem still remain unclear. The problem can be resolved by investigating the highly non-uniform distribution of disease within the vasculature. The En face method of Sudan-IV stained aorta provides a reliable approach to delineate the distribution and localization of atherosclerotic lesions (Vanderlaan et al., 2004). However, the pattern of lesion distribution around the ostia is complex and varies with species and age.
In human neonates and infants, lesions principally occur at downstream and lateral margins of ostia with complete sparing of upstream branch points but in old people, lesions tend to develop at lateral and upstream of branches with downstream sites unaffected (Sinzinger et al., 1980; Weinberg, 2002). Similar contrasting patterns of spontaneous aortic disease were found in weanling and old New Zealand white (NZW) rabbits and a perfect spatial correlation between disease location in humans, NZW rabbits and elevated macromolecule uptake was detected (Barnes \& Weinberg, 1998; Weinberg, 2004). Furthermore, endothelial cells align themselves with the predominant flow direction

\footnotetext{
* Department of Anatomy, Wah Medical College, Wah Cantt, Pakistan.

** Department of Anatomy, Army Medical College, Rawalpindi, Pakistan.

*** Department of Anatomy, Al-Nafees Medical College, Islamabad, Pakistan.
} 
and elongate at atherosclerosis-susceptible sites where the wall shear stress is high. Al-Musawi et al. (2004) observed elongated endothelial nuclei at downstream of ostia in young rabbits and at upstream of ostia in old rabbits.

Patterns of lipid deposition were particularly studied at extremes of ages, so there must be a switch over pattern between them. In addition, different parts of aorta were not compared. Thoracic and abdominal aorta, having diverse local hemodynamics, may reflect different patterns of lesion distribution. Therefore, we investigated (i) the pattern of sudanophilic lesions at aortic ostia of cholesterol-fed adult rabbits and (ii) determined any differences in lesion distribution between descending thoracic and abdominal aorta.

\section{MATERIAL \& METHOD}

The present experimental study was carried out in the centre for research in experimental and applied medicine, Army Medical College, Rawalpindi, National University of Sciences \& Technology Pakistan, after approval by the institutional animal ethical committee. Ten adult males (aged 7 to 8 months), NZW rabbits, were obtained from the National Institute of Health, Islamabad (NIH). Rabbits were individually caged at $21 \pm 2^{\circ} \mathrm{C}$ on a 12 hour light/ dark cycle. Each animal was given 100 g/day regular rabbit chow (NIH). Water was available ad libitum. After an acclimatization period of seven days, regular diet of each animal was enriched with $2 \mathrm{~g}$ cholesterol powder (Applichem, Germany). By the end of six weeks, all rabbits were euthanized with ether anesthesia. Blood samples were taken at week zero and at week six for the determination of serum cholesterol, triglycerides, LDL and HDL (Pioneer diagnostic kits, USA). Aorta was removed from each animal and placed in $10 \%$ buffered formalin. Following 48 hours of fixation, each aorta was opened longitudinally (descending thoracic along its ventral wall and abdominal aorta along its dorsal wall), rinsed in $70 \%$ alcohol and immersed in Herxheimer's solution [containing Sudan-IV (5 g), 70\% ethyl alcohol (500 ml) and acetone (500 $\mathrm{ml}$ ] at room temperature for 15 minutes. The tissues were transferred to $80 \%$ ethanol for 20 minutes and washed in running water for 1 hour to remove excess staining (Amom et al., 2008). Luminal surface was then assessed for sudanophilic lesions. Mean lesion frequencies upstream, downstream and at lateral to the affected ostia of descending thoracic and abdominal aorta were calculated. Frequencies were first compared within each part and then between the two parts of aorta.

Statistical Analysis. Data were entered in a database using SPSS windows version 16. Paired sample \#' $t$ ' test was used for testing the differences between initial and final lipid profile values of animals while comparisons between different patterns of lesion distribution (upstream, downstream, lateral margins of ostia) were carried out through Chisquare test. All the results were considered statistically significant at a $\mathrm{P}$ value less than 0.05 .

\section{RESULTS}

Highly significant increases $(\mathrm{P}<0.001)$ in the serum levels of total cholesterol, triglycerides, LDL and HDL were detected at the end of experiment compared to their baseline levels (Fig. 1).

Sudan-positive lesions were found in all aortas but not at each ostium. The fraction of affected ostia was used as an index of disease severity.

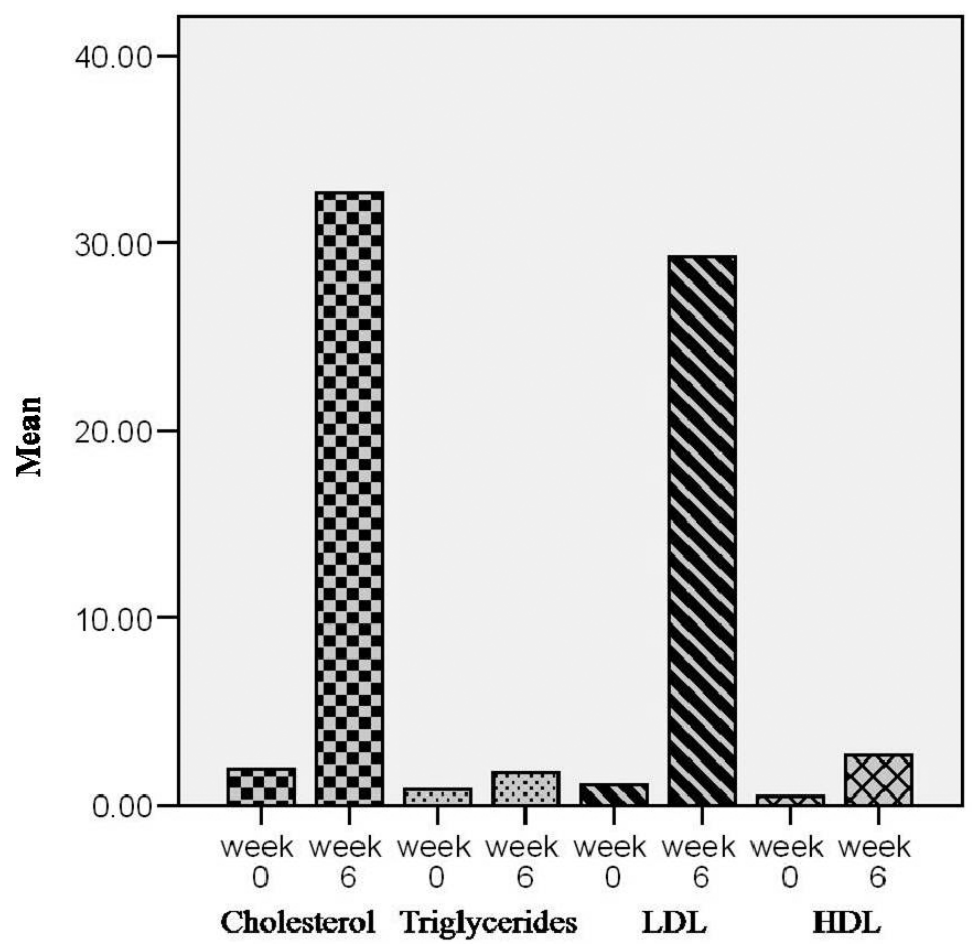

Fig. 1. Serum lipid parameters of rabbits at the start (week 0) and at the end (week 6) of experiment. 

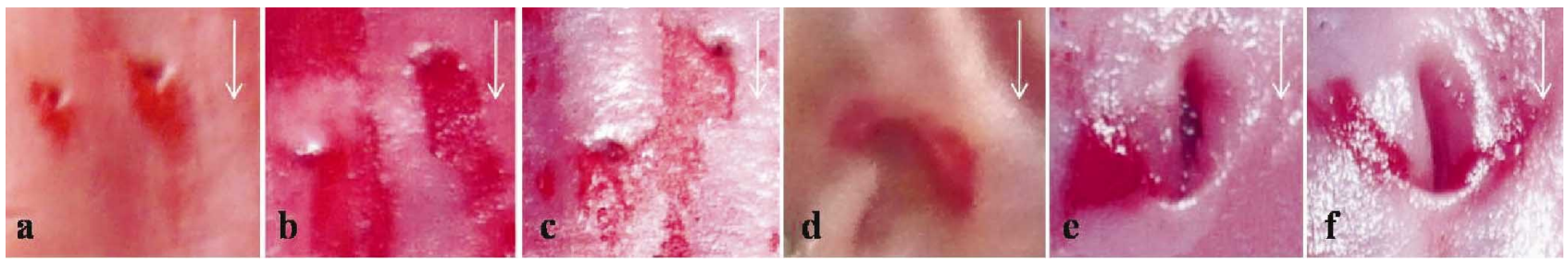

Fig. 2. Sudan-positive red lesions are downstream and lateral to ostia of intercostals arteries (a, b, c) while lesions are upstream and lateral to various ostia of abdominal aorta $(\mathrm{d}, \mathrm{e}, \mathrm{f})$ in cholesterol-fed adult New Zealand White rabbits. Arrow indicates proximal to distal direction.

Table I. Frequencies of sudanophilic lesions at upstream, downstream and lateral to the affected ostia of aorta in cholesterol-fed adult rabbits.

\begin{tabular}{lccccccc}
\hline & $\begin{array}{c}\text { Diseased } \\
\text { ostia }\end{array}$ & \multicolumn{2}{c}{ Pattern of lipid deposition at affected ostia } & & \multicolumn{2}{c}{ P-value } \\
\cline { 3 - 8 } & $(\%)$ & $\begin{array}{c}\text { Upstream } \\
(\%)\end{array}$ & $\begin{array}{c}\text { Downstream } \\
(\%)\end{array}$ & $\begin{array}{c}\text { Lateral } \\
(\%)\end{array}$ & $\begin{array}{c}\text { Upstream } \\
\text { versus } \\
\text { downstream }\end{array}$ & $\begin{array}{c}\text { Upstream } \\
\text { versus } \\
\text { lateral }\end{array}$ & $\begin{array}{c}\text { Downstream } \\
\text { versus lateral }\end{array}$ \\
\hline Descending thoracic & 32 & 2 & 95 & 92 & 0.000 & 0.000 & 0.370 \\
Abdominal & 25 & 43 & 9 & 100 & 0.017 & 0.000 & 0.000 \\
P-value & & 0.000 & 0.000 & 0.109 & & \\
\hline
\end{tabular}

Within descending thoracic aorta, disease was detected around 50 of the 156 ostia examined $(32 \%)$. Peak lesion frequencies were observed downstream (95\%) and at lateral margins (92\%) while upstream lips were least affected $(2 \%)$. Statistically highly significant difference was found in lesion frequencies at downstream versus upstream $(\mathrm{P}<0.001)$ and at lateral versus upstream $(\mathrm{P}<0.001)$ whereas an insignificant difference was observed at downstream versus lateral margins of affected ostia $(\mathrm{P}>0.05)$.

Regarding abdominal aortic-ostia, disease was present in 23 of 90 ostia examined (25\%). Lateral margins were always involved (100\%), followed by upstream (43\%) while minimal lesion frequencies were seen at downstream branch points $(9 \%)$. Statistically significant difference was observed in lesion frequencies at lateral versus downstream $(\mathrm{P}<0.001)$, lateral versus upstream $(\mathrm{P}<0.001)$, and upstream versus downstream of affected ostia $(\mathrm{P}<0.05)$.

Comparison between descending thoracic and abdominal aorta showed an insignificant difference of lesion frequencies at lateral margins $(\mathrm{P}>0.05)$ but a highly significant difference at upstream versus downstream of ostia $(\mathrm{P}<0.001)$. Upstream ostia of descending thoracic aorta and downstream ostia of abdominal aorta were spared of lesions (Table I, Fig. 2).

\section{DISCUSSION}

Morphological patterns of lipid deposition in the arterial wall correlate with the potential mechanisms involved in atherogenesis (Weinberg, 2004). Several animal models of human atherosclerosis were attempted for topographic distribution of atherosclerotic lesions. Discrepancies still exist on account of different variables like species, age, method of induction of atherosclerotic lesions, and the sites studied. Topographic study of Sudanophilic lesions was conducted in the aortas of cholesterol-fed mature minipigs and regions of high atherosclerosis-probability were detected at the lateral leading edges of flow divider (Cornhill et al., 1985). However, immature minipigs were not studied. Mature white Carneau pigeons were known to develop lesions upstream of aortic branches as those in elderly humans (Cornhill et al., 1980) but they failed to exhibit a switch from a downstream to an upstream pattern with age. In apolipoprotein E/low density lipoprotein receptor double-knockout mice, no definite pattern of arterial Sudanophilic lesions was found. Unlike humans, all three regions (upstream, downstream, and lateral to ostia) were equally affected. So knockout mice appeared inferior to other species for exploring the pattern of human lipid deposition (McGillicuddy et al., 2001).

Only cholesterol-fed NZW rabbits showed lesions similar in morphology and distribution, parallel with age, as in humans (Weinberg, 2004). But most of the studies focused on extremes of ages and particularly at intercostals-ostia. We investigated adult NZW rabbits and compared descending thoracic and abdominal aorta. Ascending and arch of aorta were excluded as these aortic parts are highly atherosclerosis-prone and lesions, here, completely 
surround the orifices. So patterns of lesion development are difficult to demonstrate in these parts of aorta (Vanderlaan et al.; Lin et al., 2007). Interestingly, descending thoracic and abdominal aorta showed contrasting patterns. Lesions were downstream and at lateral margins of ostia in descending thoracic aorta while at upstream and lateral margins of ostia in abdominal aorta. The highest lesion frequencies at ostia of descending thoracic aorta occurred at sites with the lowest frequencies at ostia of abdominal aorta (Table I). Barnes \& Weinberg (1999) induced atherosclerotic lesions in immature rabbits (aged 1.5 months) and mature rabbits (aged 12 to 14 months) with $0.05 \%$ to $0.2 \%$ dietary cholesterol for 15 weeks and noticed lipid deposition downstream and sides of branches (arrowhead shape with the tip pointing downward) in descending thoracic aorta and downstream, at the sides, and upstream of celiac ostia. However, they used low cholesterol diet for a longer period and rests of ostia in abdominal aorta other than celiac ostia were not reported. Our results are in supportive context with Barakat et al. (1992) who found enhanced permeability sites distal to ostia in descending thoracic aorta and proximal to celiac ostium in adult NZW rabbits. Regional variations of arterial wall structure and hemodynamics were accounted for this non-uniform distribution. Comparably, Sloop et al. (1998) identified two distinct morphologic patterns of fatty streaks at intercostal branches of 74 aortas from the pathobiological determinants of atherosclerosis in Youth study. In the first pattern, lipid deposition was observed lateral to ostia, with sparing upstream and downstream. The second pattern, predominated in older subjects and smoker, was characterized by broad bands of intense stain extending to the proximal edges of ostia.

We concluded that juvenile pattern of lipid deposition persists at ostia of descending thoracic aorta while a switch towards the pattern of old subjects occurs at ostia of abdominal aorta in cholesterol-fed adult rabbits. Ability to demonstrate the pattern of lesions will help in defining sampling sites and recognizing arterial properties that differ between upstream and downstream of ostia in different parts of aorta, at different ages.

SHAHID, U.; BUTT, S. A. \& ZAREEN, N. Patrones de lesiones sudanofílicas en el ostio de la aorta torácica descendente y abdominal en conejos adultos alimentados con colesterol. Int. J. Morphol., 29(3):742-746, 2011.

RESUMEN: Las lesiones ateroscleróticas Sudán-positivas se producen preferentemente en los márgenes posteriores y laterales del ostio de las ramas arteriales en neonatos humanos y en conejos destetados, pero tienden a desarrollarse en los márgenes laterales y superiores en sujetos de edad avanzada. Investigamos el patrón de lesiones sudanofílicas en el ostio aórtico de conejos adultos alimentados con colesterol y determinamos las diferencias en la distribución de lesiones entre la aorta torácica descendente y abdominal. Diez conejos machos blancos adultos New Zealand fueron alimentados con una dieta alta en colesterol al 2\%. Después de seis semanas, fueron extraídas las aortas, se disecaron longitudinalmente y se tiñeron con Sudan-IV para el examen macroscópico y se observaron las lesiones ateroscleróticas. Fueron examinados 156 ostios de aortas torácicas descendentes y 90 de aortas abdominales. Fueron calculadas y comparadas las frecuencias medias de lesiones superiores, inferiores y de los márgenes laterales de los ostios afectados. Las lesiones sudanofílicas se detectaron en alrededor del $32 \%$ de ostios de la aorta torácica descendente y en el 25\% de las aortas abdominales. En el ostio de la aorta torácica descendente, las frecuencias de lesiones fueron significativamente mayores ( $\mathrm{p}<0,001)$ por superior $(95 \%)$ y en los márgenes laterales $(92 \%)$ que por inferior (2\%). En la aorta abdominal, los márgenes laterales (100\%) y superiores $(43 \%)$ fueron significativamente más afectados ( $\mathrm{p}<0,05)$, mientras que las frecuencias mínimas de lesiones se observaron en los puntos de la rama descendente (9\%). La comparación entre la aorta torácica descendente y abdominal mostró una diferencia no significativa de las frecuencias de lesiones en los márgenes laterales ( $\mathrm{p}>0,05)$, pero muy significativa al comparar el margen superior con el inferior ( $\mathrm{p}<0,001)$. Llegamos a la conclusión que en los conejos adultos alimentados con colesterol, el patrón juvenil de deposición de lípidos por inferior persiste en el ostio de la aorta torácica descendente, mientras que se produce un cambio del modelo en los sujetos de mayor edad hacia superior del ostio de la aorta abdominal.

PALABRAS CLAVE: Lesión sudanofílica; Aorta; Ostio; Conejos.

\section{REFERENCES}

Al-Musawi, S. L.; Bishton, J.; Dean, J.; Williams, S.; Cremers, S. G. \& Weinberg, P. D. Evidence for a reversal with age in the pattern of near-wall blood flow around aortic branches. Atherosclerosis, 172(1):79-84, 2004.

Amom, Z.; Zakaria, Z.; Mohamed, J., Azlan, A.; Bahari, H.; Baharuldin, M. T. H.; Moklas, M. A.; Osman, K.; Asmawi, Z. \& Hassan, M. K. N. Lipid lowering effect of antioxidant alpha lipoic acid in experimental atherosclerosis. J. Clin. Biochem. Nutr., 43(2):88-94, 2008.

Barakat, A. I.; Uhthoff, P. A. \& Colton, C. K. Topographical mapping of sites of enhanced HRP permeability in the normal rabbit aorta. J. Biomech. Eng., 114(3):283-92, 1992. 
Barnes, S. E. \& Weinberg, P. D. Contrasting Patterns of Spontaneous Aortic Disease in Young and Old Rabbits. Arterioscler. Thromb. Vasc. Biol., 18(2):300-8, 1998.

Barnes, S. E. \& Weinberg, P. D. Two Patterns of Lipid Deposition in the Cholesterol-Fed Rabbit. Arterioscler. Thromb. Vasc. Biol., 19(10):2376-86, 1999.

Cornhill, J. F.; Barrett, W. A.; Herderick, E. E.; Mahley, R. W. \& Fry, D. L. Topographic study of sudanophilic lesions in cholesterol-fed minipigs by image analysis. Arteriosclerosis, 5(5):415-26, 1985.

Cornhill, J. F.; Levesque, M. J. \& Nerem, R. M. Quantitative study of the localization of sudanophilic coeliac lesions in the White Carneau pigeon. Atherosclerosis., 35(1):103-110, 1980.

Lin, M. S.; Hsu, H. C.; Lin, L. C.; Li, H. Y.; Lee, B. C.; Lee, Y. T.; \& Chen, M. F. Higher glutathione peroxidase expression in thoracic aorta as a protective factor against oxidative stress and atherosclerosis in rabbits. Cardiology, 108(4):381-6, 2007.

McGillicuddy, C. J.; Carrier, M. J. \& Weinberg, P. D. Distribution of lipid deposits around aortic branches of mice lacking LDL receptors and apolipoprotein E. Arterioscler. Thromb. Vasc. Biol., 21(7):1220-5, 2001.

Sinzinger, H.; Silberbauer, K. \& Auerswald, W. Quantitative investigation of sudanophilic lesions around the aortic ostia of human fetuses, newborn and children. Blood Vessels, 17(1):44-52, 1980.

Sloop, G. D.; Perret, R. S.; Brahney, J. S. \& Oalmann, M. A description of two morphologic patterns of aortic fatty streaks, and a hypothesis of their pathogenesis. Atherosclerosis, 141(1):153-60, 1998.

Vanderlaan, P. A.; Reardon, C. A. \& Getz, G. S. Site specificity of atherosclerosis. Site-selective responses to atherosclerotic modulators. Arterioscler. Thromb. Vasc. Biol., 24(1):12-22, 2004.

Weinberg, P. D. Disease patterns at arterial branches and their relation to flow. Biorheology, 39(3-4):533-7, 2002.

Weinberg, P. D. Rate-limiting steps in the development of atherosclerosis: The response-to-influx theory. J. Vasc. Res., 41(1):1-17, 2004.
Correspondence to:

Dr. Uzma Shahid

Department of Anatomy

Wah Medical College

Wah Cantt

PAKISTAN

Tel: +92 3005120496

Email: ua7567@gmail.com

Received: 14-03-2011

Accepted: 02-05-2011 